\title{
Tube Formation in Pomatoceros triqueter $\mathbf{L}$.
}

\author{
By
}

Dr. H. Faouzi.

With 3 Figures in the Text.

As a serpulid, Pomatoceros triqueter L. realises to the highest degree the adaptation to a sedentary life. The calcareous tube in which this annelid lives is characterised by a keel running along its upper surface. It is rather misleading to say that this tube is triangular in section. Figure 2 shows a newly formed calcareous rod; it is spur-shaped; the two rami of the spur might approach each other so nearly as to simulate an almost complete tube. The substratum in this species not only serves as a support, but completes the tube. This is in accordance with the fact that the tubes of Pomatoceros never extend freely off the support as happens with tubes of other serpulids-Protula, for instance. The aim of this paper is to record some observations on the way an adult Pomatoceros endeavours to build a new calcareous tube if it is artificially removed from its old one. I undertook this observation as original work at Roscoff, where a complete literature was not available. I discovered later that Harms, in the course of his research on regeneration in Hydroides pectinata, arrived at identical results. My paper cannot therefore pretend to more than a confirmation of previous results.

The Pomatoceros is removed from its tube, and placed carefully in a flat-bottomed dish full of sea-water. The worm lies on its side, its abdomen curved in a dorsal direction, performing a forward and backward undulation. If the individual happens to be sexually mature, its first preoccupation is to throw off its sexual elements-pink eggs or whitish spermatozoa - in such a quantity that one can notice with the naked eye floculent material streaming out from among the gills, and colouring the water. Through the binocular it can easily be seen that these elements stream through the fæcal groove, from its posterior end, follow its bend at the thorax, until they leave the head on its dorsal surface, to pass freely into the sea-water. Once the annelid has exhausted its sexually-mature contents, nothing more notable is to be observed for some hours (usually 6 to 10). Then a certain turbidity begins to show in the fold of the collar, just in the middle third of each side of this organ. Figure 1 shows how in 
the natural disposition of the collar there is a crest in the middle which divides it, so to speak, into two parts. This crest is orange-coloured normally and by the time the fold shows the white turbidity, this crest begins to whiten. A little later the turbidity definitely forms two white rods, occupying always the middle-third of both sides of the fold; the crest follows by forming in its fold another rod. These white rods were proved to be calcareous, and the process itself showed subsequently how we were in presence of a newly forming tube.

Active secretion of the collar adds to the substance of the laterallyplaced calcareous rods, and they lengthen in this way until they attain a position vertically above the calcareous crest already mentioned, in

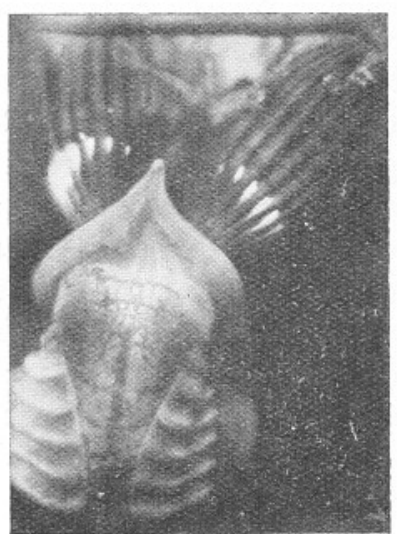

Ventral view.

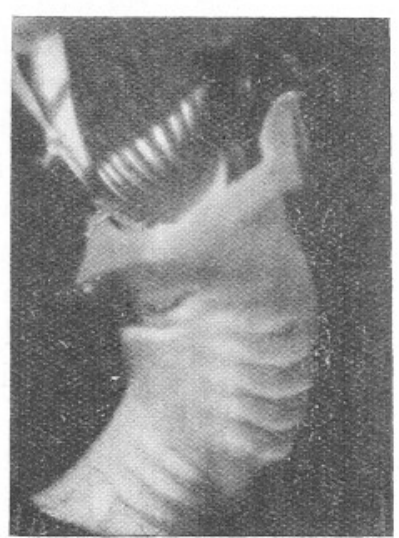

Lateral view.

FIG. 1.-Microphotograph of the anterior half of a Pomatoceros deprived of its tube, to show the folded collar with a crest in the middle.

which they fuse, and we have at last a spur-shaped piece reproducing exactly the space in the fold of the collar, with its ventrally situated crest. Figure 2 shows a piece of this type formed by one of the worms and thrown accidentally off the worm. As a matter of fact, the least shock at this moment is sufficient to provoke this accident.

The next step is the lengthening of the spur-rami dorsally; the free ventral extremities of the collar come nearer to each other but never to such an extent as to join the rami together. Here lies the explanation of the incomplete tube of the Pomatoceros of which mention was made above. This does not mean that where a complete tube is found in the serpulid a complete collar is to be expected. I have examined a Protula-a species with a complete tube-which has none the less an incomplete collar. The collar is so flabby in Protula, compared with that of Pomatoceros, so easily pliable as to be able to surround completely 
the dorsal side of the thorax, a fact which facilitates the joining of both rami in this species and the formation of a complete tube.

Calcareous secretion goes on as described, but this time increasing the surface of the rod; one should imagine a long series of spur-shaped pieces formed continuously and as a whole until a definitely-formed Pomatoceros tube is produced. The keel is due to the calcareous crest formed in the ventrally situated collar-fold. To come back again to Protula-a species with a completely round tube-one notes the absence of this particular fold characteristic of serpulids with keeled tubes.

Pomatoceros is then capable of reconstituting its tube. This notion is rather theoretical, and practically these worms are unable to resist the all-powerful circumstances that surround them, once they lose their shell. I have succeeded in keeping alive a single Pomatoceros for forty

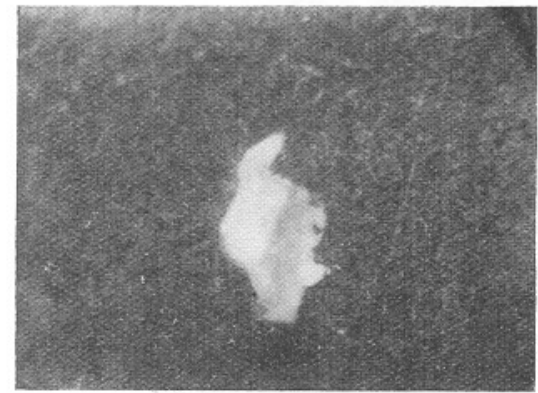

Lateral view.

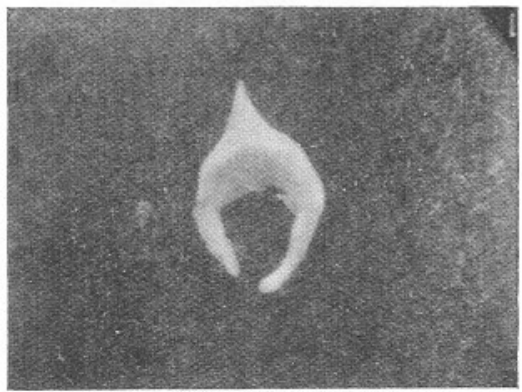

Face view.

Fig. 2.-Microphotograph of a spur-shaped calcareous piece, formed in the fold of the collar and removed accidentally. The point of the spur is the origin of the keel to be seen on the upper surface of tubes of Pomatoceros.

days; I had to protect it and, so to speak, help it to live. One of the reasons for this difficulty must first be excluded, as it is the condition sine qua non of any calcareous formation whatsoever: the calcareous reserve once exhausted, the animal is unable to form a new tube. It thus happened at Roscoff that I found worms that either did not form calcareous rods at all, or, once these rods formed, secretion did not go on any further. These cases were rather rare at Roscoff between August and September. At Plymouth I tried to repeat the experiment with a view to procuring material for cytological examination; on twenty worms removed by the method I described, not a single one gave evidence of regenerative activities. This happened in April, and points perhaps to some relation with sexual activity which did not manifest itself in April at Plymouth, while sexually mature Pomatoceros were the rule at Roscoff in August and September.

Then comes the absolute absence of defence on the part of the worm 
deprived of its tube. Active planktonic fauna, floating in the aquarium tank, crustaceans and small annelids, surround the naked worm, in search of the least breach in the surface of its body to start their work of destruction.

As regards the Pomatoceros that I succeeded in keeping for forty days

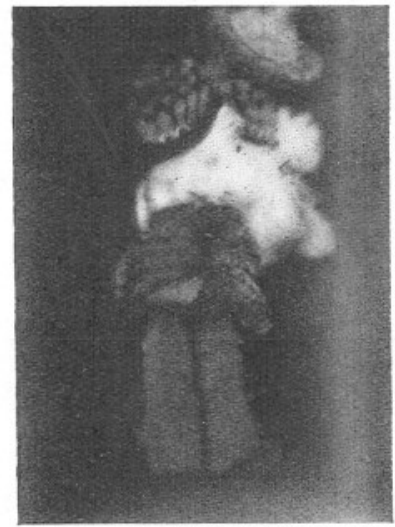

Ventral view

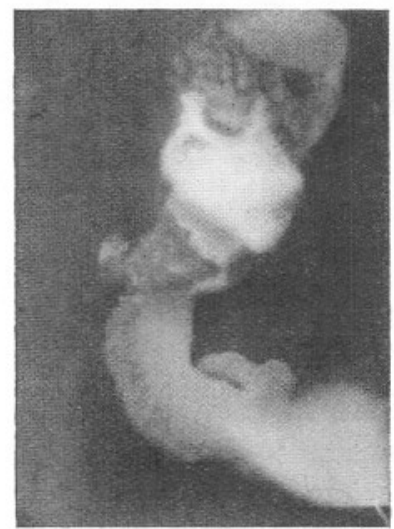

Left-lateral.

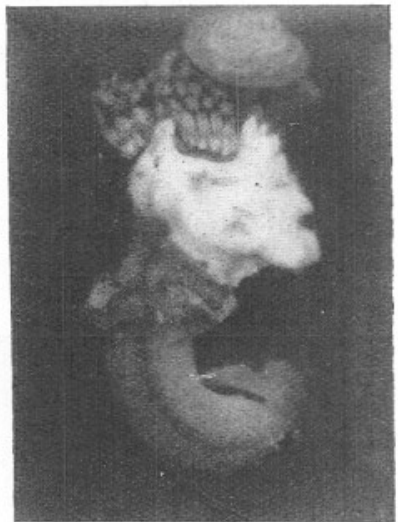

Ventro-lateral.

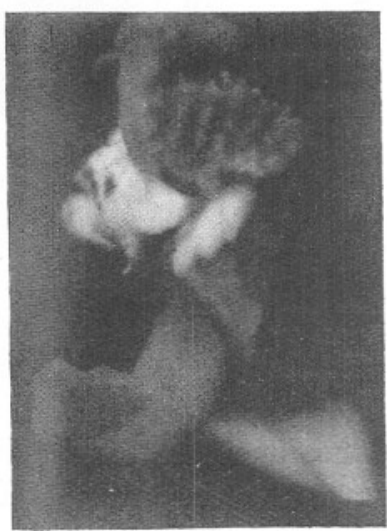

Right-lateral.

FIG. 3.-Pomatoceros which continued forming a tube for forty days: the various views of the worm show the irregular tube, formed as usual but displaced from time to time owing to the continued movement of the naked serpulid; the spur points do not correspond as they should do under normal conditions to form a single continuous keel.

(Fig. 3) I had to take many precautions : cleaning vessels daily, managing to get rather clean sea-water by passing it through a series of siphons, taking off particles of excreta and foreign matter from the body of the worm. The Pomatoceros went on forming a tube, but did not succeed in 
fixing that tube. This is due to the continual movement of the abdomen. The ventro-dorsal movement proves very deleterious to the fine calcareous rods, lying loose in the fold of the collar; the least shock is sufficient to displace these rods, or even the well-formed spur. It was by mere chance that one Pomatoceros out of piany was able to go on secreting a continuous piece for forty days, and even in this case the calcareous ring was displaced, not enough to leave the worm entirely, but to turn in a circular direction, the keel coming to a lateral position. A study of the accompanying figures shows how irregular this tube is; it presents as many keels as there were displacements : after each turning of the calcareous ring, the worm proceeded with its new tube formation, and thus the new keel did not come in line with the old one and so on. I saw later how Harms succeeded in helping a Hydroides pectinata to fix its tube to the substratum by ablation of the abdomen. I wonder if the Pomatoceros could have resisted this drastic measure?

However this may be, it is seen how the conditions described contribute to the failure of real tube regeneration; by real is meant a tube that covers completely the worm and allows it to continue living. Observation of the larvæ might reveal in this connexion very interesting details.

\section{LITERATURE.}

Claparède, E. Recherches sur la structure des Annélides Sédentaires. Mém. de la Soc. de Phys. et d'Hist. nat., T. XXII. Genève, 1873.

Fauvel, P. Recherches sur les Ampharétiens. Thèse de Sciences, Paris, 1897. Bull. Scient. France et Belg., T. XXX.

Gourret, P. Sur quelques Annélides sédentaires (genre Hydroides, Pomatoceros et Hermella) du Golfe de Marseille. C. R. Assoc. française avancement de Sci., 30. Ajaccio, 1901.

Hargitt, C. W. The behaviour of tubicolous annelids. Biol. Bull. Woods Hole. Vol. 22, 1912.

Harms, W. Beobachtungen über den natürlichen Tod der Tiere. I. Mitt: Der Tod bei Hydroides pectinata Phil. nebst Bemerkungen über die Biologie dieses Wurmes, Zool. Anz., Bd. 40. Leipzig, 1912.

Meyer, Ed. Studien über den Körperbau den Anneliden. Mitteilungen aus der Zoologischen Station zu Neapel, Bd. 8, 1888.

Prenant, M. Contribution à l'étude cytologique du calcaire. Bull. biol. Paris. T. LVIII, Fasc. 3, 1924. 
Quatrefages, De. Hist. Nat. des Annelés marins et d'eau douce. T. II (pp. 412-415). Paris, 1865.

Schiveley, M. A. Structure and development of Spirorbis borealis. Proc. Ac. Nat. Sc., Philadelphia, 1897.

Soulier, A. Études sur quelques points de l'anatomie des Annélides tubicoles de la Région de Cette. Thèse de Paris, Trav. Inst. Zool. Montpellier et Stat. Mar. Cette. Nouv. Ser. Mém., No. 2, 1891.

Watson, A. Note on the habits and building organ of the tubicolous polychæte worm Pectinaria (Lagis) koreni. Rep. Brit. Assocn., 1913 (1914). 